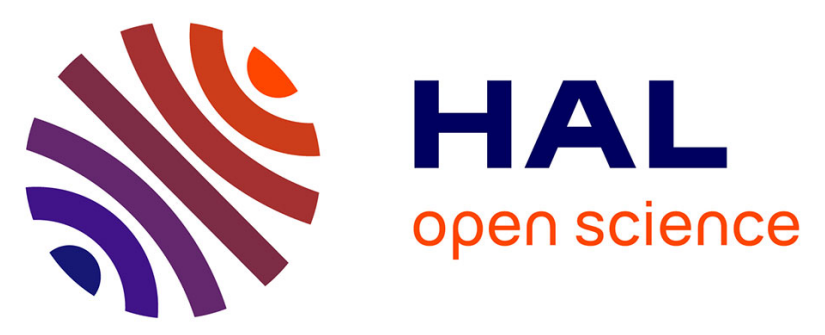

\title{
Volatile terpenoids and tropolones in heartwood extracts of yellow-cedar, Monterey cypress, and their hybrid Leyland cypress
}

Rick G. Kelsey, M. P. González-Hernández, Joe Karchesy, Sheeba Veluthoor

\section{- To cite this version:}

Rick G. Kelsey, M. P. González-Hernández, Joe Karchesy, Sheeba Veluthoor. Volatile terpenoids and tropolones in heartwood extracts of yellow-cedar, Monterey cypress, and their hybrid Leyland cypress. Annals of Forest Science, 2015, 72 (3), pp.349-355. 10.1007/s13595-014-0429-6 . hal-01284178

\section{HAL Id: hal-01284178 \\ https://hal.science/hal-01284178}

Submitted on 7 Mar 2016

HAL is a multi-disciplinary open access archive for the deposit and dissemination of scientific research documents, whether they are published or not. The documents may come from teaching and research institutions in France or abroad, or from public or private research centers.
L'archive ouverte pluridisciplinaire HAL, est destinée au dépôt et à la diffusion de documents scientifiques de niveau recherche, publiés ou non, émanant des établissements d'enseignement et de recherche français ou étrangers, des laboratoires publics ou privés. 


\title{
Volatile terpenoids and tropolones in heartwood extracts of yellow-cedar, Monterey cypress, and their hybrid Leyland cypress
}

\author{
Rick G. Kelsey • M. P. González-Hernández • \\ Joe Karchesy • Sheeba Veluthoor
}

Received: 14 July 2014 / Accepted: 3 October 2014 /Published online: 17 October 2014

(C) INRA and Springer-Verlag France 2014

\begin{abstract}
- Key message Leyland cypress, an intergeneric hybrid, produces the same volatile heartwood compounds as its parental taxa, yellow-cedar and Monterrey cypress. However, the proportion of total sesquiterpenes and some of the individual components appear unique to their respective heartwoods.

- Context Leyland cypress, xHesperotropsis leylandii is an intergeneric hybrid between yellow-cedar, Callitropsis nootkatensis, and Monterey cypress, Hesperocyparis macrocarpa. Their heartwoods are protected by bioactive compounds and rated very durable to durable for products used above ground. Several compounds in yellow-cedar and
\end{abstract}

Handling Editor: Jean-Michel Leban

Contribution of the co-authors Kelsey contributed to designing the experiment, locating and sampling trees, lab analyses, and writing the paper. González-Hernández contributed to sampling trees, lab analyses, and writing the paper. Karchesy and Veluthoor contributed to compound identification and reviewing the paper.

R. G. Kelsey $(\bowtie)$

USDA Forest Service, PNW Research Station, Corvallis, OR 97331, USA

e-mail: rkelsey@fs.fed.us

M. P. González-Hernández

Department of Crop Production, Santiago de Compostela University, 27002 Lugo, Spain

e-mail: pilar.gonzalez@usc.es

J. Karchesy

Wood Science and Engineering, Oregon State University, Corvallis, OR 97331, USA

e-mail: joe.karchesy@oregonstate.edu

S. Veluthoor

CoreValleys Herbal Technologies, Mini-Industrial Estate, Nallalam, Calicut 673027, Kerala, India

e-mail: sheeba.veluthoor@gmail.com
Monterrey cypress heartwoods are also active against various fungi, bacteria, human insect pests, and plant pathogens, whereas Leyland cypress heartwood has never been thoroughly investigated.

- Aims The first aim for this study was to examine the volatile compounds in ethyl acetate extracts from the heartwood of all three tree species in Oregon. The second aim was to determine the extent Leyland cypress differs from its parental species, and further investigate any of its novel compounds for biological activity.

- Methods Ethyl acetate extracts of fresh heartwood were prepared for three trees of each species and analyzed by gas chromatography.

- Results Thirty-three compounds were detected at $0.5 \%$ or greater abundance across all species, and 23 were identified. Carvacrol was the major monoterpene and nootkatin the most abundant tropolone in all three species. Valencene 11, 12-diol and nootkatone topped the list of sesquiterpenes in yellowcedar and Leyland cypress, respectively, whereas no sesquiterpenes were detected in Monterrey cypress. This appears to be the first report of tropolones hinokitiol, procerin, and nootkatin in Leyland cypress, $\alpha$-thujaplicinol, pygmaein, and procerin in Monterrey cypress, and hinokitiol in yellowcedar.

- Conclusions Leyland cypress heartwood does not biosynthesize structurally unique compounds from those produced by its parental species, and is an unlikely source of novel biocides. However, the proportion of total sesquiterpenes and some of the individual components in Leyland cypress heartwood may distinguish it from the heartwood of its parental species.

Keywords Cupressaceae $\cdot$ Callitropsis nootkatensis . Hesperocyparis macrocarpa $\cdot \mathrm{xHesperotropsis} \mathrm{leylandii} \mathrm{.}$ Monoterpenes $\cdot$ Sesquiterpenes 


\section{Introduction}

Yellow-cedar (YC), Callitropsis nootkatensis (D. Don) Oerst. ex D.P. Little., also known as Alaska-cedar, Alaska yellowcedar, or Nootka cypress, has experienced numerous nomenclature changes in recent years, as reviewed by Garland and Moore (2012). It is most abundant in the coastal forests of southeast Alaska and British Columbia with a southern extension of its distribution primarily in the Cascade Range through Washington and Oregon to northern California, usually at elevations above $600 \mathrm{~m}$ (Harris 1990; Murray 2010; Hennon et al. 2012). It is an ecologically and economically important tree that indigenous peoples have valued and used for centuries as a material resource (Stewart 1984; Hennon et al. 2012). Products made from its durable heartwood will last longer when used above ground, compared to those having constant contact with the soil (DeGroot et al. 2000; Hennon et al. 2007). Above ground performance is demonstrated by deadstanding YC trees that gradually lose their bark and sapwood, leaving predominately heartwood skeletons that can remain standing for up to a century after death with minimal loss in wood strength (McDonald et al. 1997). Heartwood durability is attributed to a mixture of various monoterpenes, sesquiterpenes, and tropolones (Carlsson et al. 1952; Duff et al. 1954; Erdtman and Topliss 1957; Erdtman and Hirose 1962; Norin 1964; Kelsey et al. 2005; Khasawneh and Karchesy 2011; Khasawneh et al. 2011) that have proven biological activity against various insects and microbes (Morales-Ramos et al. 2003; Arango et al. 2004; Panella et al. 1997, 2005; Taylor et al. 2006; Manter et al. 2006, 2007; Jordan et al. 2012).

Monterey cypress (MC), Hesperocyparis macrocarpa (Hartw.) Bartel has also experienced numerous nomenclature changes in recent years (Garland and Moore 2012) and is endemic to small areas around Monterey Bay and the central coast of California. This tree has been cultivated in Hawaii and elsewhere around the world for wind breaks or an ornamental with potential as an important timber species in New Zealand (Little and Skolmen 1989; Nicholas 2014). MC heartwood, like YC is more durable for above ground products than those in contact with soil; it is rated very durable to durable against brown-rot decay (Jones et al. 2013). It is known to contain some of the same bioactive monoterpenes and tropolones as YC (Corbett and Wright 1953; Haluk and Roussel 2000; Igri et al. 1990; Zhang et al. 2012).

Leyland cypress (LC), xHesperotropsis leylandii (A. B. Jacks. \& Dallim.) Garland and Gerry Moore has also experienced nomenclature instability associated with phylogenetic research as reviewed by Garland and Moore (2012). Its origin as a putative spontaneous hybrid between cultivated $\mathrm{YC}$ and MC in the UK (Ovens et al. 1964) has been confirmed by genetic studies (Yamaguchi et al. 2000; Adams et al. 2006). Geographic separation has prevented the hybridization of these species in the wild. Until recently, LC was commonly considered sterile; it may be self-sterile, but can produce viable seeds when crossed with a compatible pollen donor (Armitage 2011). The 15 cultivars of LC (Armitage 2011) are propagated as clonal cuttings primarily for ornamental trees and shrubs, but it can be grown for timber (Nicholas 2014). Like the parental species, LC heartwood is best for products used above ground, and considered very durable to durable against brown-rot decay (Jones et al. 2013), but its chemical composition has not been thoroughly investigated.

Composition of the steam distilled essential oils, and ether extracts from one tree of each of the three taxa above have been examined (Liu 2009). However, oils collected after 6 h of distillation had a substantially different composition from oils collected from 6 to $12 \mathrm{~h}$. This may be due to various factors, including nootkatin crystallization out of the essential oil (Liu 2009) and thermal instability of some compounds during steam distillation. The objectives for this study were to examine the volatile compounds in ethyl acetate extracts from all three species growing in Oregon to determine to what extent LC differs from its two parental species, and whether it contains any novel compounds worthy of investigating for biocidal activity.

\section{Material and methods}

\subsection{Plant material}

Heartwood samples were collected from three trees of each species at the locations listed in Table 1. The geographic

Table 1 Tree diameters and locations in Oregon

\begin{tabular}{llll}
\hline Species & Tree & Dbh $(\mathrm{cm})$ & Location; latitude, longitude \\
\hline YC & 1 & 38.1 & Corvallis, PA; 44.655793,$-123.234268^{\circ}$ \\
& 2 & 39.9 & \\
& 3 & 37.6 & \\
MC & 1 & 57.7 & Newport, OCA; 44.616962,$-124.050060^{\circ}$ \\
& $2^{\text {a }}$ & 101.3 & Newport, BHM; 44.631375,$-124.058188^{\circ}$ \\
& $3^{\text {a }}$ & 64.5 & Newport, PMHC; $44.632637^{\circ},-124.048309^{\circ}$ \\
LC & 1 & 35.3 & Dillard; 43.080601,$-123.409100^{\circ}$ \\
& 2 & 36.1 & \\
& 3 & 33.5 &
\end{tabular}

Trees were sampled 18-24 October, 2013. All YC trees and MC tree 1 had multiple stems. The geographic origin of YC seeds was unavailable from the arboretum. LC was cultivar 'Leighton Green'according to their owner. This cultivar is believed to be an F1 hybrid (Ovens et al. 1964)

$D b h$ diameter at breast height $(1.4 \mathrm{~m}), Y C$ yellow-cedar, $M C$ Monterrey cypress, $L C$ Leyland cypress, $P A$ Peavy Arboretum, $O C A$ Oregon Coast Aquarium, BHM Burrows House Museum, $P M H C$ Pacific Maritime and Heritage Center

${ }^{\mathrm{a}}$ Heart rot in center of these stems, only the solid heartwood was used, tree 3 was sampled on the West side as the North side was not accessible 
origins for the $\mathrm{YC}$ seed sources were unavailable from the arboretum allowing the possibility they are half-siblings from the same cone bearing tree, and the LC are clones of the same cultivar. Stem diameters were measured and cores taken at $1.4 \mathrm{~m}$ (breast height, DBH) with one core from the north and another from the south sides of each tree. The cores were $5 \mathrm{~mm}$ in diameter and penetrated to the center of each stem, except those with heartrot (Table 1). The heartwood was removed from each core and combined by tree into a sealed vial, then immediately frozen with dry ice for transport to the laboratory where they were stored frozen.

\subsection{Extractions}

In preparation for extraction, the cores from each tree were cut into thin disks (0.5-1.0 $\mathrm{mm}$ aprox.) and thoroughly mixed. Two-gram subsamples of MC and LC, and a $1 \mathrm{~g}$ subsamples of YC were sealed in smaller vials after adding $10 \mathrm{~mL}$ of ethyl acetate (EMD Chemicals, HPLC grade). Less YC tissue was used because of its higher extractive content (unpublished observations). The samples were extracted $16 \mathrm{~h}$ at room temperature and then transferred to a vial containing $1 \mathrm{~g}$ of anhydrous sodium sulfate powder (Acros, $99 \%$ ) to remove residual water.

\subsection{GC-FID and GC-MS analysis}

The percentage composition of volatiles in the extracts was determined on a Hewlett Packard (HP, currently Agilent, USA) 5890 Series II gas chromatograph (GC) with a DB-5 column $(30 \mathrm{~m} \times 0.25 \mathrm{~mm}, 0.25-\mu \mathrm{m}$ film thickness, J\&W Scientific from Agilent, USA) connected to a flame ionization detector using helium as the carrier gas at $1.0 \mathrm{~mL} / \mathrm{min}$ set at $60{ }^{\circ} \mathrm{C}$. The injector and detector temperatures were 250 and $300{ }^{\circ} \mathrm{C}$, respectively. The column oven program started at $60{ }^{\circ} \mathrm{C}$ and increased $3{ }^{\circ} \mathrm{C} / \mathrm{min}$ up to $250{ }^{\circ} \mathrm{C}$, with no final hold. Two microliter of extract was injected using the splitless mode. The mean ( \pm standard error) percentage composition of each compound in a taxa are presented in Table 2 for those compounds averaging $0.5 \%$ or higher in at least one species, but still reported in the other taxa if at lower amounts. One sample from each species was mixed with a solution containing multiple hydrocarbon standards and analyzed to calculate the arithmetic indices (AI) (Adams 2007).

Compound identity was achieved using the same GC with a DB-5MS column $(30 \mathrm{~m} \times 0.25 \mathrm{~mm}, 0.25-\mu \mathrm{m}$ film thickness, J\&W Scientific from Agilent, USA) connected to an HP 5972 mass selective detector with injector and detector temperatures as above. The helium carrier flow was $0.5 \mathrm{~mL} / \mathrm{min}$ set at $80{ }^{\circ} \mathrm{C}$. The oven program was held $80^{\circ} \mathrm{C}$ for $1 \mathrm{~min}$ then increased $5{ }^{\circ} \mathrm{C} / \min$ up to $150{ }^{\circ} \mathrm{C}$, then $3{ }^{\circ} \mathrm{C} / \min$ up to $250{ }^{\circ} \mathrm{C}$, with no final hold. One extract of each species was analyzed after concentration with a $\mathrm{N}_{2}$ stream. Two microliter of each concentrated sample was injected using the splitless mode. Compounds were identified by comparison of their spectra with those in the Adams (2007) or NIST08 (U.S. Dept. Commerce 2008) libraries in conjunction with their AI values (Adams 2007).

\section{Results}

In total, there were 33 compounds representing three structural classes (monoterpenes, sesquiterpenes, or tropolones) at a mean $0.5 \%$ composition or greater in at least one species (Table 2). Twenty-three compounds were identified, and 10 remain unknown. YC and LC heartwoods were chemically more diverse than $\mathrm{MC}$, as they synthesized compounds in all three structural classes, while MC produced no sesquiterpenes. The heartwood chemistry of LC reflects its hybrid origin, yielding totals for each structural class intermediate between YC and MC. The proportions of most individual LC compounds were similar to one of the parental species, or intermediate between them, except $\alpha$-terpineol, methyl carvacrol, procerin isomer, and unknown compounds number 6 and 18. LC produced only one compound not detected in either parental species (no. 12, unknown MW 204). The only compounds exclusive to $\mathrm{YC}$ and $\mathrm{MC}$ were $\beta$-bisabolenol and $\alpha$ thujaplicinol, respectively.

Total monoterpenes were notably higher in MC heartwood extracts $(53.2 \%)$ compared to LC (34.5\%), or YC (8.9\%). Carvacrol was the most abundant monoterpene in all three species, followed by terpinen-4-ol. The individual compounds in this class were present more consistently in all species than compounds belonging to the other two classes.

Sesquiterpenes represented $56.8 \%$ of the total volatile composition in YC heartwood and $18.2 \%$ in LC. There were no sesquiterpenes produced in MC heartwood. Valencene 11 , 12-diol (16.8 \%), nootkatol (10.6\%), and nootkatone (8.2\%) were the three most abundant sesquiterpenes in YC extracts, compared with nootkatone (7.9\%), valencene 11, 12-diol $(2.6 \%)$, and valencene $(2.3 \%)$ in LC.

Total tropolones were most abundant (38.6\%) and structurally diverse in MC heartwood, including six identified compounds and one potential isomer of procerin, with nootkatin $(23.3 \%)$ and hinokitiol $(7.2 \%)$ in the highest amounts. LC had intermediate proportions of total tropolones $(30.0 \%)$ and produced the same compounds as in MC except for $\alpha$-thujaplicinol, although $\alpha$-thujaplicin and pygmaein were in low amounts. Nootkatin $(14.5 \%)$ and hinokitiol $(8.4 \%)$ were the two most abundant tropolones in LC. YC had the lowest total tropolone composition (13.8\%), and less structural diversity, producing only four of the compounds found in $\mathrm{MC}$, including the procerin isomer. Nootkatin $(6.4 \%)$ and procerin $(5.7 \%)$ were the top two tropolones in 
Table 2 The volatile composition (mean $\% \pm$ SE) of ethyl acetate extracts from heartwood of yellow-cedar (YC), Leyland cypress (LC), and Monterey cypress (MC) growing in Oregon ( $n=3$ trees per species)

\begin{tabular}{|c|c|c|c|c|c|c|c|}
\hline \multirow[t]{2}{*}{ No. } & \multirow[t]{2}{*}{ Compound } & \multirow[t]{2}{*}{$\mathrm{YC}$} & \multirow[t]{2}{*}{$\mathrm{LC}$} & \multirow[t]{2}{*}{$\mathrm{MC}$} & \multicolumn{2}{|l|}{$\mathrm{AI}$} & \multirow[t]{2}{*}{ Class } \\
\hline & & & & & Measured & Adams $^{\mathrm{e}}$ & \\
\hline 1 & Terpinen-4-ol & $1.05 \pm 0.04$ & $2.45 \pm 0.02$ & $2.99 \pm 0.16$ & 1179 & 1174 & M \\
\hline 2 & $\alpha$-Terpineol & $0.29 \pm 0.04$ & $0.51 \pm 0.01$ & $0.38 \pm 0.08$ & 1193 & 1186 & M \\
\hline 3 & Methyl carvacrol & $0.38 \pm 0.19$ & $1.25 \pm 0.22$ & $0.73 \pm 0.28$ & 1245 & 1241 & M \\
\hline 4 & Carvacrol & $7.13 \pm 2.25$ & $30.26 \pm 1.19$ & $49.06 \pm 5.67$ & 1302 & 1298 & M \\
\hline 5 & Unknown MW 168 & $0.09 \pm 0.06$ & $0.85 \pm 0.04$ & $1.27 \pm 0.10$ & 1309 & & \\
\hline 6 & Unknown MW 170 & $0.27 \pm 0.02$ & $0.74 \pm 0.03$ & $0.23 \pm 0.09$ & 1323 & & \\
\hline 7 & Unknown MW 170 & $0.51 \pm 0.05$ & $0.54 \pm 0.03$ & $0.27 \pm 0.10$ & 1374 & & \\
\hline 8 & $\alpha$-Thujaplicin & $0 \pm 0$ & $0.10 \pm 0.00$ & $1.50 \pm 1.15$ & 1417 & 1410 & $\mathrm{~T}$ \\
\hline 9 & Unknown MW 166 & $0.54 \pm 0.08$ & $0 \pm 0$ & $0.52 \pm 0.12$ & 1464 & & \\
\hline 10 & Unknown MW 166 & $0.89 \pm 0.07$ & $0.80 \pm 0.01$ & $0 \pm 0$ & 1466 & & \\
\hline 11 & Hinokitiol ( $\beta$-thujaplicin) & $0.93 \pm 0.13$ & $8.38 \pm 0.66$ & $7.21 \pm 1.86$ & 1484 & 1475 & $\mathrm{~T}$ \\
\hline 12 & Unknown MW 204 & $0 \pm 0$ & $0.58 \pm 0.01$ & $0 \pm 0$ & 1492 & & \\
\hline 13 & Valencene & $2.69 \pm 0.20$ & $2.25 \pm 0.11$ & $0 \pm 0$ & 1500 & 1496 & $\mathrm{~S}$ \\
\hline 14 & $\beta$-Bisabolene & $1.11 \pm 0.17$ & $0.48 \pm 0.01$ & $0 \pm 0$ & 1513 & 1505 & $\mathrm{~S}$ \\
\hline 15 & $\alpha$-Thujaplicinol & $0 \pm 0$ & $0 \pm 0$ & $2.35 \pm 1.21$ & 1515 & 1509 & $\mathrm{~T}$ \\
\hline 16 & Nootkatene & $2.71 \pm 0.31$ & $0.66 \pm 0.03$ & $0 \pm 0$ & 1522 & 1517 & S \\
\hline 17 & 7-epi- $\alpha$-Selinene ${ }^{\mathrm{a}}$ & $0.65 \pm 0.07$ & $0.15 \pm 0.01$ & $0 \pm 0$ & 1531 & 1520 & $\mathrm{~S}$ \\
\hline 18 & Unknown MW 198 & $0.63 \pm 0.11$ & $1.46 \pm 0.02$ & $0 \pm 0$ & 1563 & & \\
\hline 19 & Pygmaein & $0 \pm 0$ & $0.03 \pm 0.01$ & $0.82 \pm 0.35$ & 1588 & 1581 & $\mathrm{~T}$ \\
\hline 20 & $\alpha$-Cadinol $^{\mathrm{a}}$ & $0.84 \pm 0.03$ & $0.27 \pm 0.02$ & $0 \pm 0$ & 1664 & 1652 & $\mathrm{~S}$ \\
\hline 21 & Intermedeol $^{\mathrm{a}}$ & $0.59 \pm 0.03$ & $0.25 \pm 0.01$ & $0 \pm 0$ & 1667 & 1665 & S \\
\hline 22 & epi-Nootkatol & $2.83 \pm 0.36$ & $0.58 \pm 0.04$ & $0 \pm 0$ & 1707 & 1699 & S \\
\hline 23 & Nootkatol & $10.59 \pm 2.17$ & $2.16 \pm 0.15$ & $0 \pm 0$ & 1723 & 1714 & $\mathrm{~S}$ \\
\hline 24 & Valencene 13-ol & $7.33 \pm 2.16$ & $0.52 \pm 0.03$ & $0 \pm 0$ & 1778 & 1767 & S \\
\hline 25 & $\beta$-Bisabolenol & $0.79 \pm 0.18$ & $0 \pm 0$ & $0 \pm 0$ & 1794 & 1789 & S \\
\hline 26 & Nootkatone & $8.19 \pm 0.26$ & $7.94 \pm 0.13$ & $0 \pm 0$ & 1817 & 1806 & S \\
\hline 27 & Kudtdiol & $1.75 \pm 0.07$ & $0.38 \pm 0.00$ & $0 \pm 0$ & 1919 & 1912 & $\mathrm{~S}$ \\
\hline 28 & Valencene 11,12-diol ${ }^{\mathrm{b}}$ & $16.77 \pm 0.49$ & $2.56 \pm 0.24$ & $0 \pm 0$ & 1928 & 1914 & $\mathrm{~S}$ \\
\hline 29 & Procerin & $5.73 \pm 1.30$ & $2.65 \pm 0.17$ & $0.02 \pm 0.02$ & 1942 & 1931 & $\mathrm{~T}$ \\
\hline 30 & Unknown MW? & $0.83 \pm 0.05$ & $0.16 \pm 0.00$ & $0 \pm 0$ & 1954 & & \\
\hline 31 & Nootkatin & $6.44 \pm 0.87$ & $14.53 \pm 0.37$ & $23.29 \pm 4.04$ & 1970 & 1959 & $\mathrm{~T}$ \\
\hline 32 & Procerin isomer ${ }^{\mathrm{c}}$ & $0.71 \pm 0.13$ & $4.31 \pm 0.25$ & $3.37 \pm 1.05$ & 2008 & & $\mathrm{~T}$ \\
\hline \multirow[t]{5}{*}{33} & Unknown MW 234 & $0.90 \pm 0.26$ & $0.20 \pm 0.00$ & $0.05 \pm 0.02$ & 2123 & & \\
\hline & Total monoterpenes ${ }^{\mathrm{d}}$ & $8.85 \pm 2.45$ & $34.47 \pm 1.21$ & $53.16 \pm 5.69$ & & & \\
\hline & Total sequiterpene & $56.83 \pm 1.76$ & $18.20 \pm 0.42$ & $0 \pm 0$ & & & \\
\hline & Total tropolones ${ }^{\mathrm{d}}$ & $13.82 \pm 1.67$ & $29.99 \pm 1.30$ & $38.57 \pm 4.68$ & & & \\
\hline & Total for extract ${ }^{d}$ & $84.17 \pm 1.07$ & $88.01 \pm 0.19$ & $94.07 \pm 0.74$ & & & \\
\hline
\end{tabular}

Compounds in this study were identified by GC-MS whereas compounds $1-4,13,16,22-24,26-28$, and 31 in YC were previously identified by cochromatography with authentic standard, or isolation and identification by ${ }^{1} \mathrm{H}$ and ${ }^{13} \mathrm{C}$ NMR (Khawawneh et al. 2011; Khasawneh and Karchesy 2011) $M W$ molecular weight, $M$ monoterpene, $S$ sesquiterpene, $T$ tropolone

${ }^{\text {a }}$ Tentative identity

${ }^{\mathrm{b}}$ Khasawneh and Karchesy (2011) note this could be tedonodiol isolated by Guerreiro et al. (1979), but the later authors did not determine the stereochemistry

${ }^{\mathrm{c}} \mathrm{MW}=230$ with ion fragmentation very similar to procerin

${ }^{\mathrm{d}}$ Structural class totals do not include the unknowns, except for the procerin isomer that was included in the tropolones. The total for extract includes all compounds, including the unknowns

${ }^{\mathrm{e}}$ Adams (2007) 
YC, making nootkatin the most abundant tropolone in all three species.

\section{Discussion}

We believe this is to be the first report of hinokitiol in heartwood of YC, although its presence was suspected based on biosynthetic considerations (Little et al. 2004; Little 2006). This also appears to be the first report of $\alpha$-thujaplicinol, pygmaein, and procerin in heartwood of MC, or hinokitiol, procerin, and nootkatin in LC, based on the review of tropolones in Cupressales (Haluk and Roussel 2000), and our additional literature search. Furthermore, the compound we suspect to be a procerin isomer is potentially a new tropolone for all three species.

Our results show valencene 11, 12-diol, and nootkatone as the major sesquiterpenes in YC and LC, respectively. Live YC trees in southeast Alaska forests contained much lower amounts of valencene 11, 12-diol, ranging from 0 to $2.4 \%$ with a mean of $1.2 \%$ (authors unpublished data). The YC trees used in the present study may denote a different chemotype since their geographic origin is unknown. Carvacrol was the most abundant monoterpene in all three taxa and the major volatile component in MC heartwood as observed in other studies that include trees growing in Morroco (Igri et al. 1990; Zhang et al. 2012).

In general, the proportions of most individual compounds in LC heartwood extracts were similar to the amounts in one or the other parental species, or intermediate between them. When the compounds were totaled into monoterpene, sesquiterpene, or tropolone structural classes, the proportions for LC were intermediate between the two parental species, as might be anticipated from an F1 hybrid. The absence of sesquiterpenes in MC makes it easily distinguishable from the other two species that are chemically more similar one to one another. But, the proportions of total sesquiterpenes might also be a diagnostic characteristic for separating YC and LC heartwoods. In all samples of YC, the total sesquiterpenes have exceeded $35 \%$. From our results here, they averaged $56.8 \%$ (Table 2). In 12 live trees from natural populations across a $260-\mathrm{km}$ distance in southeast Alaska, they ranged from 37.8 to $53.6 \%$ (41.6\% mean, authors unpublished data), and in $0-6$ and 6-12-h steam distilled essential oils, they were 47.7 and $43.32 \%$, respectively (Liu 2009). In contrast, the LC here contained only $18.2 \%$ total sesquiterpenes and 11.98 and $12.39 \%$ in the $0-6$ and $6-12$-h oils (Liu 2009). If LC produces no more than half of the total sesquiterpenes as their YC parent, they would always contain less than $30 \%$ based on the YC values above. This would make LC readily distinguishable from YC with total sesquiterpenes greater than $35 \%$. Proportions of carvacrol, hinokitiol, and nootkatin might also help separate LC and YC heartwoods.
Unlike heartwood, the major sesquiterpene in LC foliage, (+)-dauca-5,8-diene is not present in either parental species (Cool 2001) making it a unique chemical characteristic. Also, the monoterpene hydrocarbon mixtures in essential oils from LC foliage are sufficiently unique to allow identification of some clones, and the grouping of others (Scheffer et al. 1980). Whether the volatile extractives in LC heartwood can provide similar clonal discrimination remains to be evaluated.

The accumulation of bioactive compounds that contribute to heartwood durability of YC and MC most likely evolved as a chemical defense against various natural enemies (MoralesRamos et al. 2003; Arango et al. 2004; DeGroot et al. 2000; Kelsey et al. 2005; Taylor et al. 2006; Hennon et al. 2007; Zhang et al. 2012). Many of these compounds may also have value as natural repellents or biocides with potential use for protecting humans, crops, and forest products from insect and microbial pests (Panella et al. 1997, 2005; Zhu et al. 2001; Haluk and Roussel 2000; Dietrich et al. 2006; Manter et al. 2006, 2007; Saniewski et al. 2007; Baser 2008; Dolan et al. 2009; Jordan et al. 2012).

\section{Conclusion}

The intergeneric hybrid gene recombination in LC does not lead to the biosynthesis of structurally unique compounds from those produced by the parental species, and therefore is an unlikely source of novel biocides. However, the proportions of total sesquiterpenes, or some of the individual compounds may provide useful chemical characteristics for separating heartwood of LC from its parental taxa.

Acknowledgments We wish to thank Ed Jensen and Rennie Ferris for helping locate trees, and the following individuals for allowing us to sample the trees under their care; MC, staff at the Oregon Coast Aquarium and Steve Wyatt at the Oregon Coast History Center; LC, James Carlson; and YC, Brent Klumph, Oregon State University College Forests. We also thank Paul Hennon for this review and helpful comments. The use of trade, firm or corporation names is for information and convenience of the reader and does not constitute an official endorsement or approval by the U.S. Department of Agriculture.

Funding The authors thank the USDA Forest Service, Pacific Northwest Research Station for funds supporting this project.

\section{References}

Adams RP (2007) Identification of essential oil components by gas chromatography/mass spectrometry, 4th edn. Allured Publishing Corp, Carol Stream

Adams RP, Rushforth K, Trimble SN (2006) The origins of Leyland's cypresses (x Cupressocyparis leylandii) based on DNA data. Phytologia 88:1-16

Arango RA, Green F III, Hintz K, Miller RB (2004) Evaluating the natural durability of native and tropical wood species against 
Reticulitermes flavipes. IRG documents 2004:IRG 35, 6-10 June 2004, Ljubljana, Slovenia. Stockholm, Sweden:IRG Secretariat, 2004

Armitage J (2011) The fertility of Leyland cypress. Plantsman 10:254 256

Baser KHC (2008) Biological and pharmacological activities of carvacrol and carvacrol bearing essential oils. Curr Pharm Design 14:31063120. doi:10.2174/138161208786404227

Carlsson B, Erdtmann H, Frank A, Harvey WE (1952) The chemistry of the Order Cupressales VIII. Heartwood constituents of Chamaecyparis nootkatensis - carvacrol, nootkatin and chamic acid. Acta Chem Scand 6:690-696

Cool LG (2001) Ent-Daucane and acorane sesquiterpenes from $\mathrm{x}$ Cupressocyparis leylandii foliage. Phytochemistry 58:969-972. doi:10.1016/S0031-9422(01)00342-9

Corbett RE, Wright DE (1953) The extractives of Libocedrus bidwillii and Cupressus macrocarpa. Chem Ind 1258-1259

DeGroot RC, Woodward B, Hennon PE (2000) Natural decay resistance of heartwood from dead, standing yellow-cedar trees: laboratory evaluations. For Prod J 50:53-59

US Dept Commerce (2008) NIST08 mass spectral library. National Institute of Standards and Technology, Standard Reference Data Program. Gaithersburg, MD 20899

Dietrich G, Dolan MC, Peralta-Cruz J, Schmidt J, Piesman J, Eisen RJ, Karchesy JJ (2006) Repellent activity of fractioned compounds from Chamaecyparis nootkatensis essential oil against nymphal Ixodes scapularis (Acari: Ixodidae). J Med Entomol 43:957-961. doi:10. 1603/0022-2585(2006)43[957:RAOFCF]2.0.CO;2

Dolan MC, Jordan RA, Schulze TL, Schulze CJ, Manning MC, Ruffolo D, Schmidt JP, Piesman J, Karchesy JJ (2009) Ability of two natural products, nootkatone and carvacrol, to suppress Ixodes scapularis and Amblyomma americanum (Acari: Ixodidae) in a lyme disease endemic area of New Jersey. J Econ Entomol 102:2316-2324. doi: $10.1603 / 029.102 .0638$

Duff SR, Erdtmann H, Harvey WE (1954) The chemistry of the Order Cupressales. II. Heartwood constituents of Chamaecyparis nootkatensis (Lamb.) Spach. Nootkatine. Acta Chem Scand 8: 1073-1082

Erdtman H, Hirose Y (1962) The chemistry of the natural order Cupressales. 46: the structure of nootkatone. Acta Chem Scand 16:1311-1314

Erdtman H, Topliss JG (1957) The chemistry of the natural order Cupressales. XVIII: Nootkatene, a new sesquiterpene type hydrocarbon from the heartwood of Chamaecyparis nootkatensis (Lamb.). Acta Chem Scand 11:1157-1161

Garland MA, Moore G (2012) xHesperotropsis, a new nothogenus for intergeneric crosses between Hesperocyparis and Callitropsis (Cupressaceae), and a review of the complicated nomenclatural history of the Leyland cypress. Taxon 61:667670

Guerreiro E, Kavka J, Giordano OS (1979) Tedonodiol, an eremophilano derivative from Tessaria dodoneifolia (Hook. et Arn.) Cabr. Anal Asoc Quim Argent 67:119-123

Haluk J-P, Roussel C (2000) Caractérisation et origine des tropolones responsables de la durabilité naturelle des Cupressacées. Application potentielle en préservation du bois. Ann For Sci 57: 819-829. doi:10.1051/forest:2000155

Harris AS (1990) Chamaecyparis nootkatensis (D. Don) Spach Alaskacedar. In: Burns R.M., Honkala B.H. (eds), Silvics of North America. Agric. Handb. 654. USDA For Ser, Washington DC, pp $97-102$

Hennon P, Woodward B, Lebow P (2007) Deterioration of wood from live and dead Alaska yellow-cedar in contact with soil. For Prod J 57:23-30

Hennon PE, D'Amore DV, Schaberg PG, Wittwer DT, Shanley CS (2012) Shifting climate, altered niche, and a dynamic conservation strategy for yellow-cedar in the north Pacific coastal rainforest. Bioscience 62:147-158. doi:10.1525/bio.2012.62.2.8

Igri MA, Holeman M, Ilidrissi A, Berrada M (1990) Principaux constituants obtenus par hydrodistillation et extraction aux solvants des rameaux et du bois de Cupressus macrocarpa Hartweg. Plantes Med Phytother 24:44-9

Jones TG, Low CB, Meder R, O'Callahan DR, Milne PG, Chittenden CM, Ebdon N, Dungey HS (2013) Heartwood of Cupressus lusitanica, C. macrocarpa, Leyland and Ovens cypress and prediction of its durability using near-infrared spectroscopy. Eur J Wood Prod 71:183-192. doi:10.1007/s00107-013-0663-x

Jordan RA, Schulze TL, Dolan MC (2012) Efficacy of plant-derived and synthetic compounds on clothing as repellents against Ixodes scapularis and Amblyomma americanum (Acari: Ixodidae). J Med Entomol 49:101-106. doi:10.1603/ME10241

Kelsey RG, Hennon PE, Huso M, Karchesy JJ (2005) Changes in heartwood chemistry of dead yellow-cedar trees that remain standing for 80 years or more in southeast Alaska. J Chem Ecol 31:26532670. doi:10.1007/s10886-005-7618-6

Khasawneh MA, Karchesy JJ (2011) Terpenoids of the heartwood of Chamaecyparis nootkatensis. Amer J Org Chem 1:1-5. doi:10. 5923/j.ajoc.20110101.01

Khasawneh MA, Xiong Y, Peralta-Cruz J, Karchesy JJ (2011) Biologically important eremophilane sesquiterpenes from Alaska cedar heartwood essential oil and their semi-synthetic derivatives. Molecules 16:4775-4785. doi:10.3390/molecules 16064775

Little DP (2006) Evolution and circumscription of the true cypresses (Cupressaceae: Cupressus). Syst Bot 31:461-480. doi:10.1600/ 036364406778388638

Little EL Jr, Skolmen RG (1989) Common forest trees of Hawaii (native and introduced). USDA For Serv Agriculture Handbook No 679, p 70. http://www.fs.fed.us/psw/publications/documents/misc/ah679. pdf

Little DP, Schwarzbach AE, Adams RP, Hsieh C-F (2004) The circumscription and phylogenetic relationships of Callitropsis and the newly described genus Xanthocyparis (Cupressaceae). Am J Bot 91:1872-1881. doi:10.3732/ajb.91.11.1872

Liu X (2009) Analysis and comparison of essential oil components extracted from the heartwoods of Leyland cypress, Alaska yellow cedar, and Monterey cypress. Master's thesis, Oregon State Univ, Corvallis, OR

Manter DK, Karchesy JJ, Kelsey RG (2006) The sporicidal activity of yellow-cedar heartwood, essential oil and wood constituents toward Phytophthora ramorum in culture. For Pathol 36:297-308. doi:10. 1111/j.1439-0329.2006.00461.x

Manter DK, Kelsey RG, Karchesy JJ (2007) Antimicrobial activity of extractable conifer heartwood compounds toward Phytophthora ramorum. J Chem Ecol 33:2133-2147. doi:10.1007/s10886-0079368-0

McDonald KA, Hennon PE, Stevens JH, Green DW (1997) Mechanical properties of salvaged dead yellow-cedar in southeast Alaska. USDA For Serv Res Pap FPL-RP-565

Morales-Ramos JA, Rojas MG, Hennon PE (2003) Black-staining fungus effects on the natural resistance properties of Alaskan yellow cedar to the Formosan subterranean termite (Isoptera: Rhinotermitidae). Environ Entomol 32:234-1241. doi:10. 1603/0046-225X-32.5.1234

Murray MD (2010) The natural range of yellow-cedar: a photographic tour of diverse locations. In: Harrington, C.A. (Tech. Coord.), A Tale of Two Cedars: International Symposium on Western Redcedar and Yellow-cedar. USDA For Serv, Gen Tech Rep PNW-GTR-828, p $149-152$

Nicholas I (ed) (2014) NZFFA Electronic Handbook Series. Best practice with farm forestry timber species. No. 1 Cypresses. http://www. nzffa.org.nz/special-interest-groups/cypress-action-group/. Accessed Feb. 2014 
Norin T (1964) Chanootin, a bicyclic C15-tropolone from the heartwood of Chamaecyparis nootkatensis (Lamb.). Spach Ark Kemi 22:129135

Ovens H, Blight W, Mitchell AF (1964) The clones of Leyland cypress. Quart J For 58:8-19

Panella NA, Karchesy J, Maupin GO, Malan JCS, Piesman J (1997) Susceptibility of immature Ixodes scapularis (Acari: Ixodidae) to plant-derived acaricides. J Med Entomol 34:340-345

Panella NA, Dolan MC, Karchesy JJ, Xiong Y, Peralta-Cruz J, Khasawneh M, Montenieri JA, Maupin GO (2005) Use of novel compounds for pest control: insecticidal and acaricidal activity of essential oil components from heartwood of Alaska yellow cedar. J Med Entomol 42:352-358. doi:10.1603/0022-2585(2005) 042[0352:UONCFP]2.0.CO;2

Saniewski M, Saniewska A, Kanlayanarat S (2007) Biological activities of tropolone and hinokitiol: the tools in plant physiology and their practical use. Acta Hort (ISHS) 755:133-142, http://www.actahort. org/books/755/755 17.htm

Scheffer JJC, Ruys-Catlender CM, Koedam A, Svendsen AB (1980) A comparative study of $\mathrm{x}$ Cupressocyparis leylandii clones
(Cupressaceae) by gas chromatographic analysis of their leaf oils. Bot J Linn Soc 81:215-224

Stewart H (1984) Cedar: tree of life to the northwest coastal Indians. Douglas \& McIntyre Ltd., Vancouver

Taylor AM, Gartner BL, Morrell JJ, Tsunoda K (2006) Effects of heartwood extractive fractions of Thuja plicata and Chamaecyparis nootkatensis on wood degradation by termites or fungi. J Wood Sci 52:147-153. doi:10.1007/s10086-0050743-6

Yamaguchi N, Shiraishi S, Sasaki Y, Yamamoto C (2000) Molecular evidence of the hybrid origins of Leyland cypress (X Cupressocyparis leylandii). J For Res 5:35-38. doi:10.1007/ BF02762761

Zhang L, Zhang Y, Li S, Karchesy JJ (2012) Cupressus macrocarpa heartwood oil and its bioactivity against some wood decay fungi. Adv Mat Res 485:413-416. doi:10.4028/ www.scientific.net/AMR. 485.413

Zhu BCR, Henderson G, Chen F, Maistrello L, Laine RA (2001) Nootkatone is a repellent for formosan subterranean termite (Coptotermes formosanus). J Chem Ecol 27:523-531 